\title{
Pliocene voles (Pliomys, Arvicolinae, Rodentia) from Odessa Catacombs
}

\begin{abstract}
Alexey S. Tesakov
ABSTRACT. The primitive arvicolid from the fauna of Odessa Catacombs (terminal Ruscinian, MN15, Early Pliocene) is described as a new species of the genus Pliomys, P. destinatus sp. nov. This form is more advanced than Pliomys kowalskii from Late Ruscinain faunas of Moldova and Ukraine in stronger reduced mimomyian ridge and enamel islet of first lower molar. P. destinatus sp. nov. is supposed to be a direct ancestor of Early Villanyian (MN16, Middle Pliocene) Pliomys jalpugensis from southern Ukraine.
\end{abstract}

KEY WORDS: Arvicolinae, evolution, Ruscinian, Early Pliocene, Odessa, Ukraine.

Alexey S. Tesakov [tesak@ginras.ru], Geological Institute of the Russian Academy of Sciences, Pyzhevsky per. 7, Moscow 119017, Russia.

\section{Плиоценовые полевки (Pliomys, Arvicolinae, Rodentia) из Одесских Катакомб}

\begin{abstract}
А.C. Тесаков
РЕЗЮМЕ. Архаичная полевка из фауны Одесских Катакомб (терминальный русциний, MN15) описывается как новый вид рода Pliomys, P. destinatus sp. nov. Эта форма более прогрессивна, чем Pliomys kowalskii из фаун позднего русциния Молдовы и Украины в большей редукции мимомисного выступа и эмалевого островка на первом нижнем моляре. Предполагается, что P. destinatus sp. nov. является прямым предком Pliomys jalpugensis из раннего виллания (средний плиоцен) южной Украины.
\end{abstract}

КЛЮЧЕВЫЕ СЛОВА: Arvicolinae, эволюция, русциний, ранний плиоцен, Одесса, Украина.

\section{Introduction}

The fauna of Odessa Catacombs is among the few fissure fillings known in the northern Black Sea region. Moreover, it is the only one of the Ruscinian age. The abundantly fossiliferous red clays fill the system of karst cavities in the Lower Pontian limestone within the city of Odessa (Ukraine). The caves were exposed by limestone mining in the first half of the last century. Rich bone materials were discovered in 1928 by T.G. Gritzai and later excavated by the paleontological expedition of the Ukrainian Academy of Sciences (Gritzai, 1938). The mammal fauna of the site is under continuous study since that time. Bones of the camel Paracamelus alexejevi (Havesson, 1950) are predominant among remains of large mammals. Also numerous and diverse are carnivorous mammals (for the review see Sotnikova, 2004).

Small mammals were described and discussed in a number of publications. They were dedicated to murids (Argyropulo \& Pidoplichko, 1939a), lagomorphs (Argyropulo \& Pidoplichko, 1939b; Gureev, 1964), beavers (Goretsky, 1943), spalacids (Topachevsky, 1969), hamsters (Topachevsky \& Scorik, 1992), preliminary data on arvicolids (Gromov \& Polyakov, 1977; Topachevsky \& Nesin, 1989). Topachevsky et al. (1998) and Nesin \& Nadachowski (2000) reviewed the taxonomic list of the locality. By now the small mammals of the Odessa Catacombs include Ochotona sp., Proochotona gigas Argyropulo \& Pidoplichka, 1939, Alilepus ucrainicus Gureev, 1964, ?Trogontherium sp., Nannospalax odessanus (Topachevsky, 1969), Orientalomys similis (Argyropulo \& Pidoplichka, 1939), Odessamys palatocristatus Topachevsky \& Scorik, 1992, Cricetinus gritzaii Topachevsky \& Scorik, 1992, Pliomys destinatus sp. nov., ?Promimomys sp.

Most researchers date the mammal association of the Odessa Catacombs to the Late Ruscinian, MN15 (Pevzner et al., 1996; Topachevsky et al., 1998; Nesin \& Nadachowski, 2000).

This paper gives a description of arvicolid material from Odessa Catacombs, the most abundant, but up to now poorly studied element of the small mammal fauna of this locality.

\section{Material}

The study is based on materials (collection EMM20) stored in the Geological Institute of the Russian Academy of Sciences (GIN). They were collected in 1989-1990 by the field parties of GIN led by M.A. Pevzner and the author. Limited but important material 
was given to me by K.K. Pronin in 1999. In addition, I had a chance to study the original materials of the expedition led by T.G. Gritzai in $30-40$-s of the $20^{\text {th }}$ century, which are currently preserved in the National Natural History Museum of the National Academy of Sciences of Ukraine, Kiev; in the Paleontological Museum of the Odessa State University (collection OSM3825), and in the Zoological Institute of the Russian Academy of Sciences in St. Petersburg.

Terminology and abbreviations. The terminology of occlusal elements of vole molars is according to van der Meulen (1973). Terms for enamel-dentine boundary (linea sinuosa) in dentition of rhizodont voles are after G. Rabeder, (1980): HH-index, the square root of the sum of heights of dentine tracts of hypoconid and hypoconulid in lower molars; PA-index, the square root of the sum of heights of dentine tracts of protocone and anterocone in upper molars; ASD - anterosinuid, HSD - hyposinuid, HSLD - hyposinulid, DS distosinus, AS - anterosinus, ASL - anterosinulus, PRS - protosinus. $\Sigma$ tract and $\Sigma$ _tract/L are respectively sum of tracts heights and index of the latter to the occlusal length of the molar (Nesin, 1988). Lower case $\mathrm{m}$ stands for lower molars; upper case M, for upper molars. GIN: Geological Institute of the Russian Academy of Sciences, Moscow. OSM: Odessa State Museum, Ukraine.

\section{Systematic Paleontology}

\section{FAMILY CRICETIDAE FISCHER VON WALDHEIM, 1817}

\section{Subfamily ARVICOLINAE Gray, 1821}

\section{Genus Pliomys Méhely, 1914}

Pliomys Méhely, 1914: 195-198; Apistomys Méhely, 1914: 203; Propliomys Kretzoi, 1959: 237-246.

Pliomys destinatus sp. nov.

Figs. 1-12, Tables 1-6.

Pliomys odessanus nom. nud.: Gromov \& Polyakov, 1977: 118.
Etymology: destinatus, from Latin resolute, determined.

Holotype. OSM-3825/01, right mandible fragment with $\mathrm{m} 1(2.9 \cdot 1.1 \mathrm{~mm})$ and $\mathrm{m} 2(1.85 \cdot 1.05 \mathrm{~mm})$. Paratype: GIN EMM-20/8, right m1, 2.45 $0.95 \mathrm{~mm}$.

Referred material: $16 \mathrm{~m} 1,17 \mathrm{~m} 2,17 \mathrm{~m} 3,27 \mathrm{M} 1,20 \mathrm{M} 2$, 18 M3 (GIN EMM-20).

Additional studied material: 1 fragmentary mandible with $\mathrm{m} 1-\mathrm{m} 3$ (GIN EMM-20/14), 2 fragmentary right mandibles with $\mathrm{m} 1$ and $\mathrm{m} 2,(\mathrm{OSM}-3825 / 02,3825 / 03)$, and isolated m1 $(3825 / 04)$.

Type locality. Odessa Catacombs, fossiliferous red clays filling karstic cavities in the Pontian limestone in Odessa, Ukraine.

Stratigraphic level. Late Ruscinian, MN15, Lower Pliocene.

Diagnosis: Species with $\mathrm{m} 1$ showing posterior lobe, three basic triangles, and anteroconid incompletely differentiated into T4 and T5 and rounded anterior cap. Mimomyian ridge nearly reduced and manifested as flattened tip of BSA3. Insular re-entrant deep, occasionally insulates at late stages of crown abrasion. In $\mathrm{m} 1 \mathrm{HH}$-index ranges from 0.4 to 0.7 ; index of sum of tracts between 65 and 75. M3 with short-living anterior and posterior enamel islets, rarely co-occurring simultaneously at certain wear stage.

Differential diagnosis. The new species differs from Pliomys kowalskii Schevtschenko, 1965 in more reduced mimomyian ridge, and higher hypsodonty with mean $\mathrm{HH}$-index more than 0.5 ; it differs from P. jalpugensis Nesin, 1983 in, on the contrary, less reduced mimomyian characters (ridge and islets) and less hypsodont molars. From P. hungaricus (Kormos, 1934) and P. ucrainicus (Topachevsky \& Scorik, 1967) it differs in rounded anteroconid cap without additional triangles T6 and T7, from the former species it additionally differs by mostly two-rooted M3.

Description. Medium size primitive brachyodont vole with enamel undifferentiated or weakly thinning in the tips of reentrant folds. The schmelzmuster is of the protopachyknem type. Trailing edges show tangential enamel, and leading edges near the tips of the triangles display some primitive lamellar enamel.

Lower jaw. A fragmental left mandible (GIN EMM20/14), belonging to a senile individual, preserves mor-

Table 1. Measurements and indices of Pliomys destinatus sp. nov., m1, Odessa Catacombs.

\begin{tabular}{|l|c|c|c|c|c|c|c|c|}
\hline & $\mathrm{n}$ & Mean & Minimum & Maximum & Std.Dev. & Std. error & CV \\
\hline LENGTH & 9 & 2.68 & 2.45 & 2.95 & 0.1622 & 0.0541 & 6.06 \\
\hline WIDTH & 14 & 1.13 & 0.95 & 1.25 & 0.0932 & 0.0249 & 8.24 \\
\hline ASD & 9 & 1.12 & 1.00 & 1.35 & 0.1228 & 0.0409 & 10.94 \\
\hline HSD & 9 & 0.51 & 0.40 & 0.60 & 0.0682 & 0.0227 & 13.49 \\
\hline HSLD & 9 & 0.26 & 0.15 & 0.40 & 0.0982 & 0.0327 & 38.45 \\
\hline HH-INDEX & 9 & 0.57 & 0.43 & 0.72 & 0.0868 & 0.0289 & 15.18 \\
\hline A/L & 9 & 46.38 & 38.60 & 52.83 & 4.4054 & 1.4685 & 9.50 \\
\hline$\Sigma$ _tract & 7 & 1.89 & 1.75 & 2.10 & 0.1239 & 0.0468 & 6.55 \\
\hline$\Sigma$ _tract/L & 7 & 71.64 & 67.31 & 73.47 & 2.0697 & 0.7823 & 2.89 \\
\hline
\end{tabular}



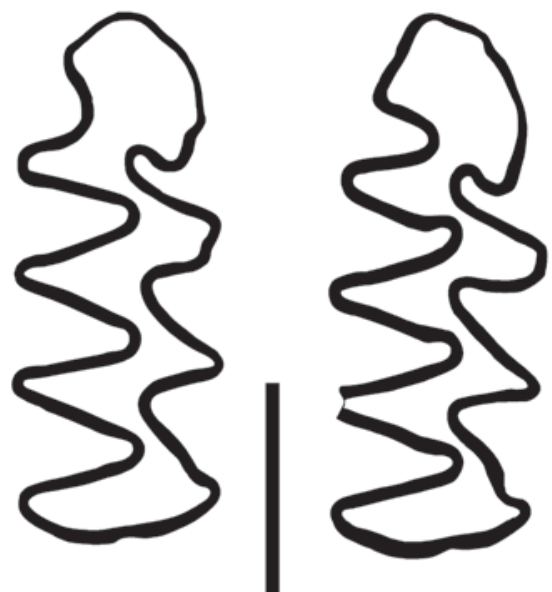

2

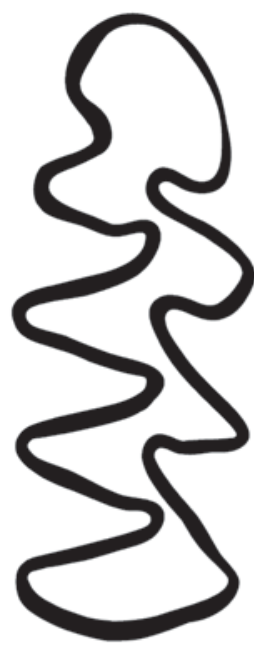

6

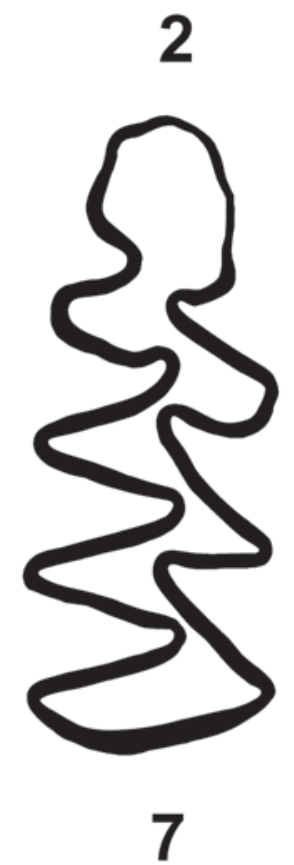

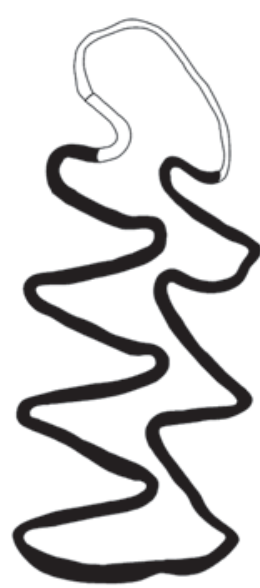

3

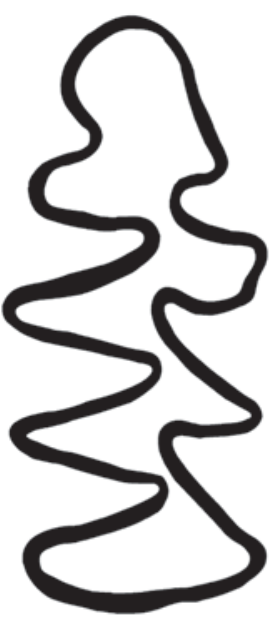

8

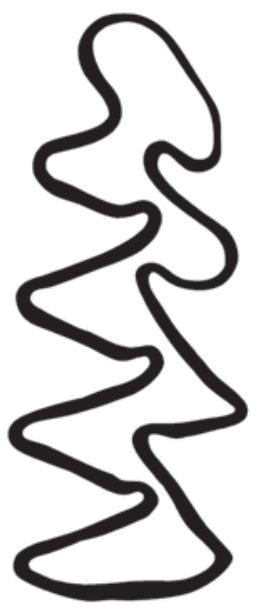

4

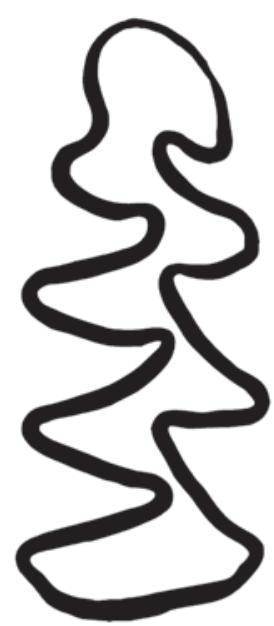

9
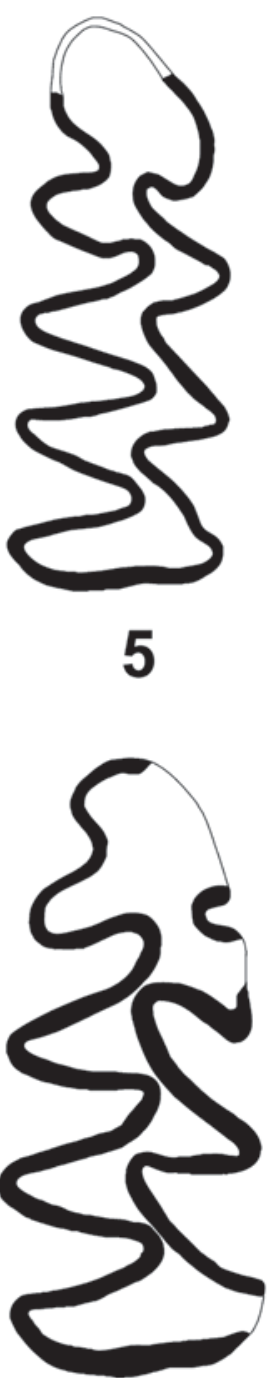

10

Figure 1. Pliomys destinatus sp. nov., m1, 1-10: occlusial surface. 1. 20/8: paratype, 2. 20/2, 3. 20/9, 4. 3825-04, 5. 20/12, 6 . 3825-01: holotype, 7. 20/11, 8. 20/13, 9. 20/4, 10. 20/14. 5, 7, 8, 10: reversed. Scale bar $1 \mathrm{~mm}$.

phology of its distal part and especially articular process (Fig. 9: 3). Distal end of the incisor forms a clear alveolar bulge on the outer side of the ascending part of mandible at the level slightly above the dental foramen. The height of the articular process above the occlusal plane amounts to $50 \%$ of the mandible height. The angle between the occlusal plane and the line drawn from the symphysis angle tangentially to the angular process ( $\alpha$ angle) is about $15^{\circ}$. The articular process is set at an angle of ca. $58^{\circ}$ to the occlusal plane of lower molars ( $\alpha$ angle). Two other studied mandibular fragments are more damaged and represent juvenile (Fig. 9: 1) and adult animals (Fig. 9:2).

m1 (Tab. 1, Figs. 1-2). Two roots. Rarely, a third small labial rootlet can be present (Fig.2: 2a). In the lateral aspect, most crowns show a characteristic bulge of the anterior side (Fig. 2: 1, 3). Occlusal dentine fields notably communicate but tend to be more subdivided with wear. Anteroconid elements are broadly confluent; the fusion of anterior cap and T5 is wider than that of T4-T5. Insular reentrant (BRA3) is deep and usually clearly curving anteriorly. Occasionally, its depth can be partly reduced by the formation of normally a very short-living enamel islet. Sometimes BRA3 becomes more shallow without distinct insulation but with a formation of a clear "shelf" homologous to enamel islet. The tip of BSA3 is blunt in most studied specimens. Sometimes it bears a poorly expressed groove (Fig. 1: 1), and only in juvenile specimens can it bear a deeper groove (Fig. 10: 1). The shape of anterior cap is from rounded to rectangular. Clear signs of the second complication of the anterior cap are not manifested. 

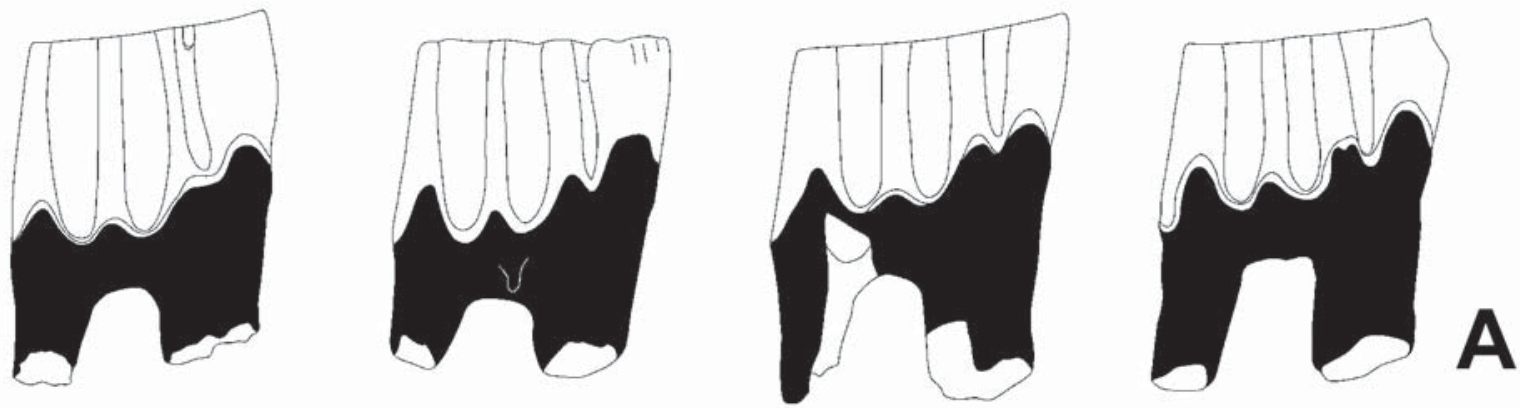

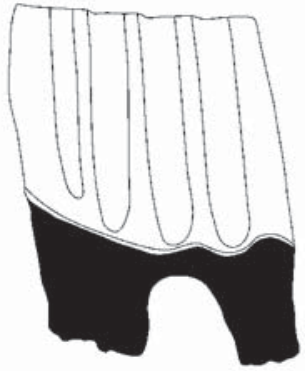

1

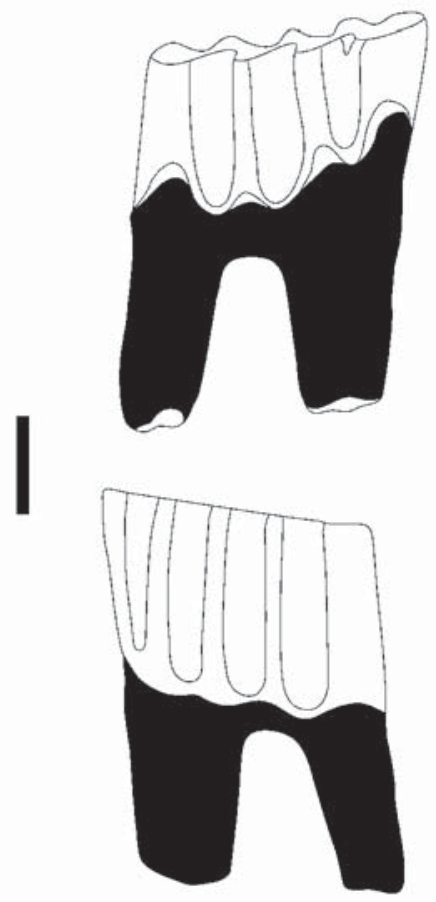

5

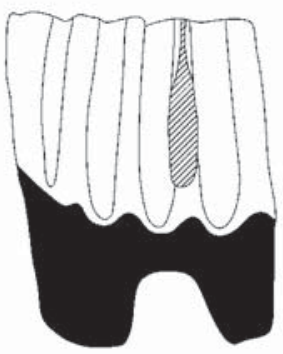

2
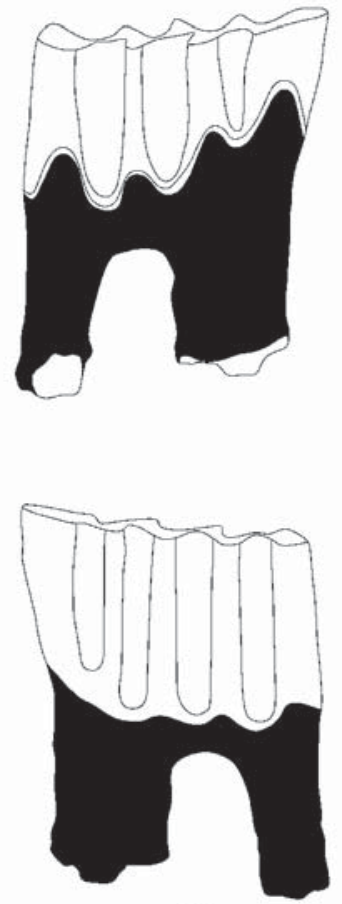

6

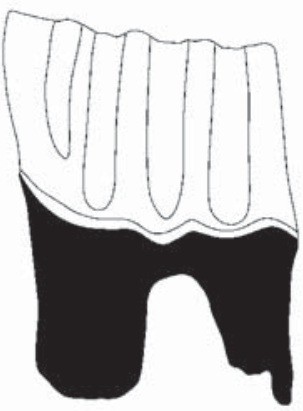

3

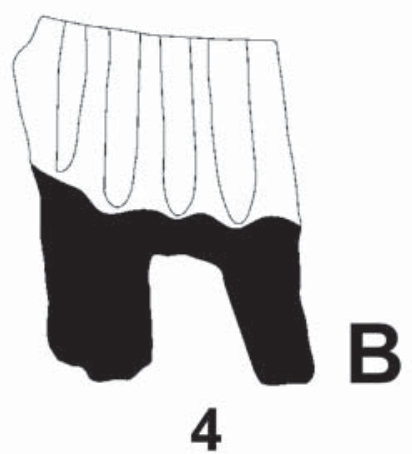

A
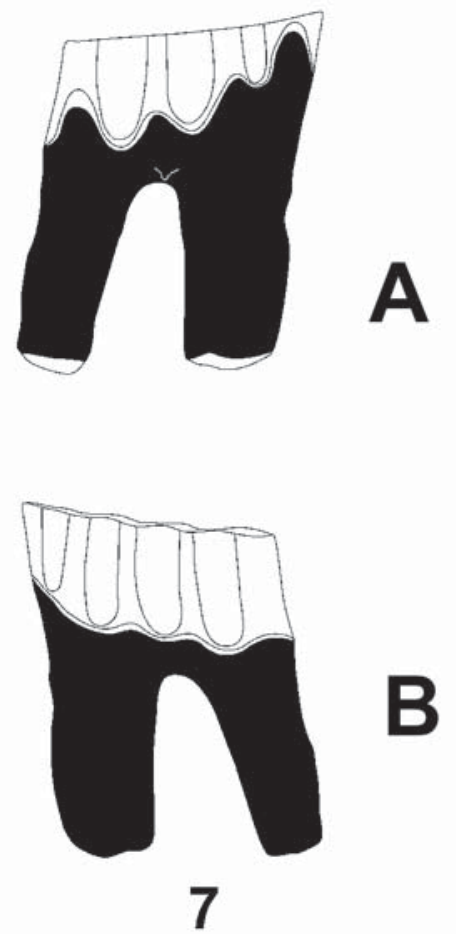

Figure 2. Pliomys destinatus sp. nov., m1, 1-7: lateral view, a: labial side, b: lingual side. 1. 20/8: paratype, 2. 20/2, 3. 382504, 4. 20/12, 5. 3825-01: holotype, 6. 20/11, 7. 20/4. 4, 6: reversed. Scale bar $1 \mathrm{~mm}$. 
Table 2. Measurements and indices of Pliomys destinatus sp. nov., m2, Odessa Catacombs.

\begin{tabular}{|l|c|c|c|c|c|c|c|c|}
\hline & $\mathrm{n}$ & Mean & Minimum & Maximum & Std.Dev. & Std. error & CV \\
\hline LENGTH & 14 & 1.72 & 1.55 & 1.90 & 0.0820 & 0.0219 & 4.77 \\
\hline WIDTH & 17 & 1.06 & 0.90 & 1.22 & 0.0914 & 0.0222 & 8.60 \\
\hline ASD & 13 & 0.60 & 0.45 & 0.80 & 0.1030 & 0.0286 & 17.06 \\
\hline HSD & 14 & 0.31 & 0.25 & 0.40 & 0.0413 & 0.0110 & 13.13 \\
\hline HSLD & 15 & 0.26 & 0.15 & 0.35 & 0.0573 & 0.0148 & 21.93 \\
\hline HH-INDEX & 14 & 0.41 & 0.29 & 0.50 & 0.0586 & 0.0157 & 14.19 \\
\hline E_tract & 12 & 1.16 & 0.95 & 1.45 & 0.1661 & 0.0479 & 14.27 \\
\hline
\end{tabular}

Anteroconid triangles (T4-T5) are distinctly separated by provergent LRA3 with not more than $1-1.5$ widths of enamel left in the dentine communication between them. The sinuous line at the enamel-dentine juncture (EDJ) is wavy with tips of anterosinuid (at the labial side of anterior cap), "mimosinuid" (BSA3), hyposinuid (BSA1), and hyposinulid (LSA1) forming the highest tracts. The EDJ on the posterior loop is commonly higher than lower edge of the adjacent lingual and labial reentrants (Fig. 2: 6).

$\mathbf{m} 2$ (Tab. 2, Fig. 3). Two roots. The posterior root is positioned upon the dorsal surface of the incisor and has a fork-like shape (full acrorhizal condition). No signs of a pleurorhizal shift trough the ontogeny are observed. The highest tracts are anterosinuid, hyposinuid, and hyposinulid. The ASD is complicated by

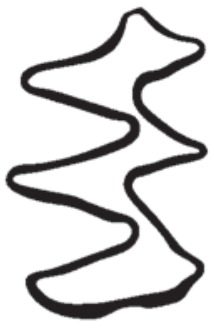

1
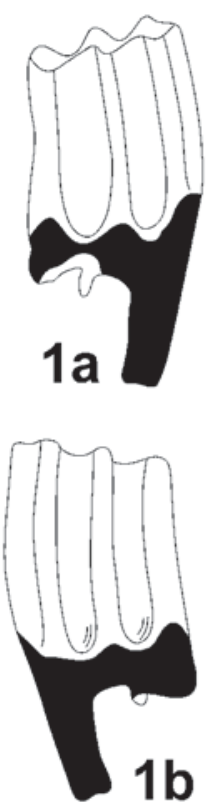

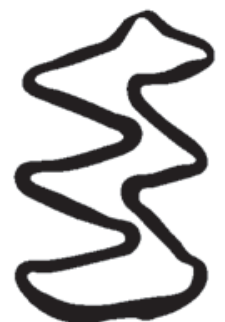

2
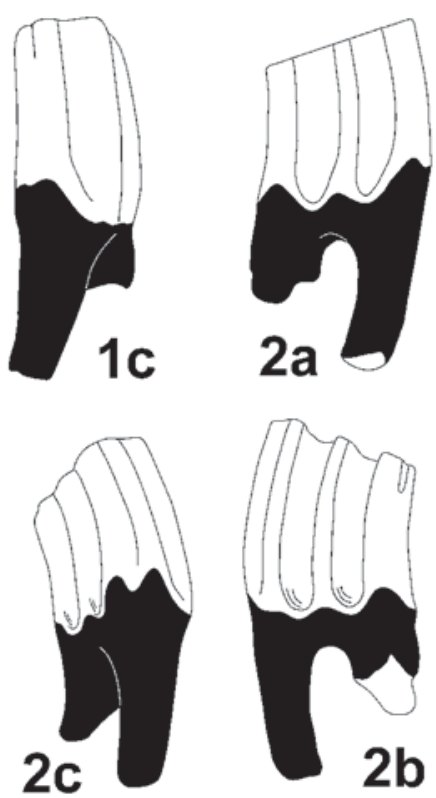
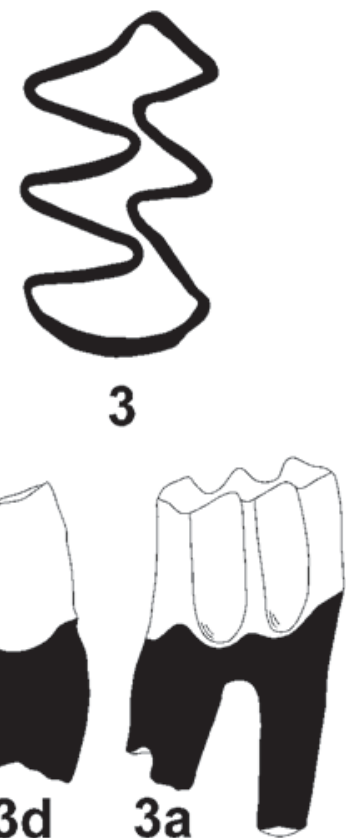

$3 d$
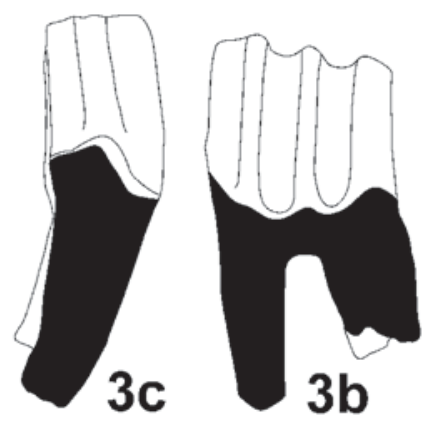
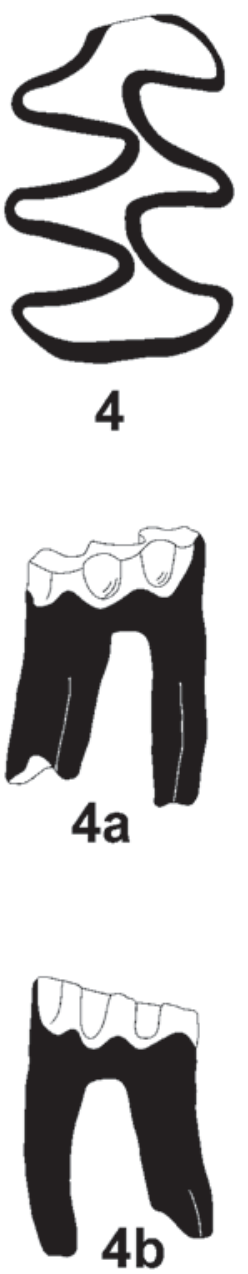

Figure 3. Pliomys destinatus sp. nov., m2, 1-4: occlusial surface, a: labial side, b: lingual side, c: anterior side, d: posterior side. 1. 20/27, 2. 20/19, 3. 3825-01: holotype, 4. 20/22. 2: reversed. Scale bar $1 \mathrm{~mm}$. 
Table 3. Measurements and indici of Pliomys destinatus sp. nov., m3, Odessa Catacombs.

\begin{tabular}{|l|c|c|c|c|c|c|c|}
\hline & $\mathrm{n}$ & Mean & Minimum & Maximum & Std.Dev. & Std. error & CV \\
\hline LENGTH & 14 & 1.45 & 1.20 & 1.55 & 0.1075 & 0.0287 & 7.42 \\
\hline WIDTH & 17 & 0.80 & 0.65 & 0.90 & 0.0766 & 0.0186 & 9.54 \\
\hline ASD & 13 & 0.55 & 0.45 & 0.85 & 0.1030 & 0.0286 & 18.60 \\
\hline HSD & 13 & 0.13 & 0.05 & 0.20 & 0.0541 & 0.0150 & 41.04 \\
\hline HSLD & 14 & 0.10 & 0.01 & 0.20 & 0.0591 & 0.0158 & 56.63 \\
\hline HH-INDEX & 13 & 0.17 & 0.07 & 0.28 & 0.0642 & 0.0178 & 37.19 \\
\hline ¿_tract & 12 & 0.80 & 0.54 & 1.00 & 0.1200 & 0.0346 & 14.96 \\
\hline
\end{tabular}

a variably expressed tract of the adjacent BSA3 thus acquiring a doubled tip (Fig. 3: 1c, 2c).

$\mathbf{m 3}$ (Tab. 3, Fig. 4). Two roots. Younger molars have deep antero-lingual reentrant (LRA3) close to the right angle. At later wear stages it becomes shallower and represents a blunt angle. Pairs of occlusal triangles, $\mathrm{T} 1$ and $\mathrm{T} 2$, and $\mathrm{T} 3$ and $\mathrm{T} 4$ are broadly confluent.

Cranial morphology. A fragment of maxillary bone with preserved left M1, alveoli of the right M1, and anterior walls of double-rooted alveoli of both M2,

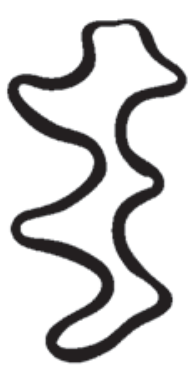

1
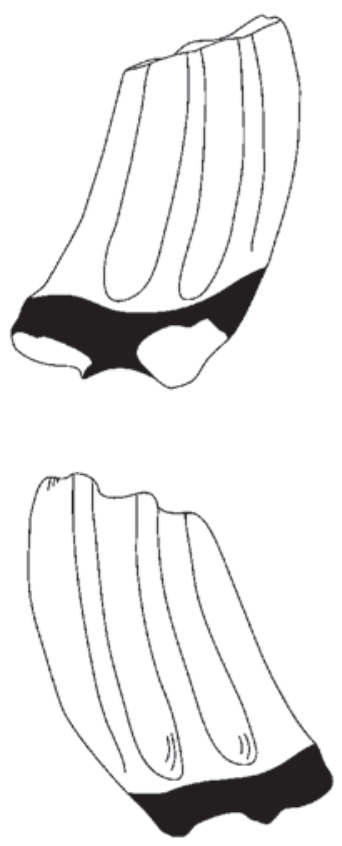

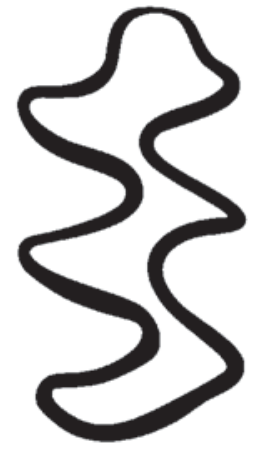

2
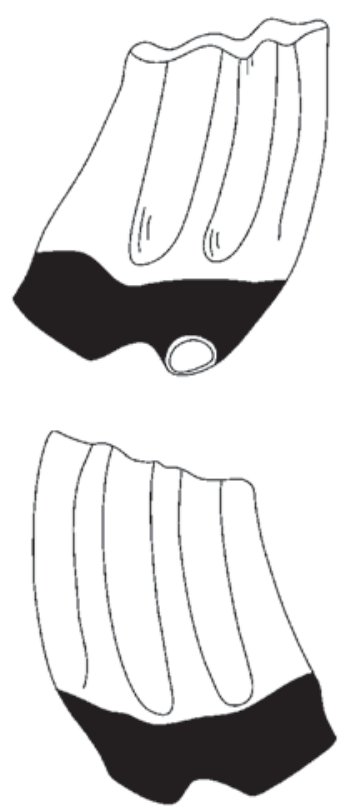

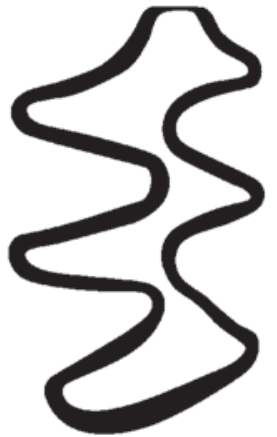

3
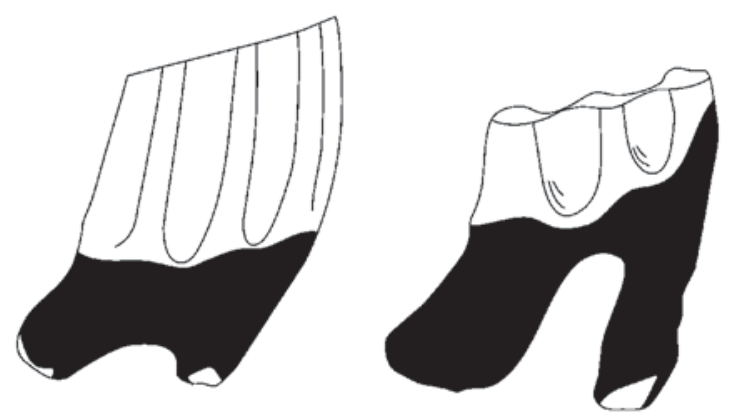

A

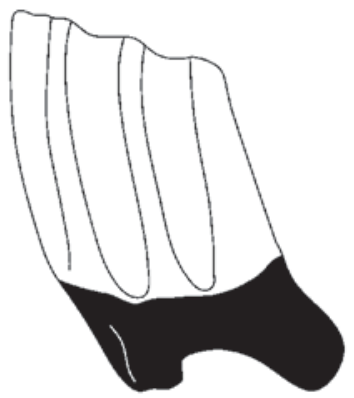

Figure 4. Pliomys destinatus sp. nov., m3, 1-4: occlusial surface, a: labial side, b: lingual side. 1. 20/45, 2. 20/37, 3. 20/38, 4. 20/40. 3, 4: reversed. Scale bar $1 \mathrm{~mm}$. 
Table 4. Measurements and indici of Pliomys destinatus sp. nov., M1, Odessa Catacombs.

\begin{tabular}{|l|c|c|c|c|c|c|c|c|}
\hline & $\mathrm{n}$ & Mean & Minimum & Maximum & Std.Dev. & Std. error & CV \\
\hline LENGTH & 20 & 2.32 & 2.10 & 2.57 & 0.1330 & 0.0297 & 5.74 \\
\hline WIDTH & 27 & 1.29 & 1.10 & 1.50 & 0.1047 & 0.0201 & 8.09 \\
\hline DS & 23 & 0.52 & 0.35 & 0.70 & 0.0903 & 0.0188 & 17.23 \\
\hline AS & 21 & 0.23 & 0.15 & 0.35 & 0.0564 & 0.0123 & 24.09 \\
\hline ASL & 20 & 0.20 & 0.05 & 0.35 & 0.0724 & 0.0162 & 37.11 \\
\hline PRS & 22 & 0.47 & 0.35 & 0.60 & 0.0882 & 0.0188 & 18.86 \\
\hline PA-INDEX & 19 & 0.53 & 0.38 & 0.65 & 0.0942 & 0.0216 & 17.94 \\
\hline E_tract & 17 & 1.41 & 1.10 & 1.75 & 0.1699 & 0.0412 & 12.03 \\
\hline
\end{tabular}

Table 5. Measurements and indici of Pliomys destinatus sp. nov., M2, Odessa Catacombs.

\begin{tabular}{|l|c|c|c|c|c|c|c|}
\hline & $\mathrm{n}$ & Mean & Minimum & Maximum & Std.Dev. & Std. error & CV \\
\hline LENGTH & 9 & 1.92 & 1.75 & 2.05 & 0.0880 & 0.0293 & 4.58 \\
\hline WIDTH & 19 & 1.18 & 1.00 & 1.35 & 0.0973 & 0.0223 & 8.21 \\
\hline DS & 10 & 0.37 & 0.25 & 0.50 & 0.0818 & 0.0259 & 22.42 \\
\hline AS & 17 & 0.27 & 0.17 & 0.40 & 0.0627 & 0.0152 & 23.24 \\
\hline ASL & 16 & 0.28 & 0.17 & 0.35 & 0.0448 & 0.0112 & 16.03 \\
\hline PA-INDEX & 16 & 0.39 & 0.28 & 0.53 & 0.0619 & 0.0155 & 15.98 \\
\hline __tract & 9 & 0.87 & 0.74 & 1.05 & 0.1149 & 0.0383 & 13.16 \\
\hline
\end{tabular}

Table 6. Measurements and indices of Pliomys destinatus sp. nov., M3, Odessa Catacombs.

\begin{tabular}{|l|c|c|c|c|c|c|c|c|}
\hline & $\mathrm{n}$ & Mean & Minimum & Maximum & Std.Dev. & Std. error & CV \\
\hline LENGTH & 15 & 1.63 & 1.42 & 1.85 & 0.1140 & 0.0294 & 7.00 \\
\hline WIDTH & 18 & 0.96 & 0.80 & 1.15 & 0.0865 & 0.0204 & 8.98 \\
\hline DS & 15 & 0.26 & 0.15 & 0.35 & 0.0651 & 0.0168 & 25.36 \\
\hline AS & 17 & 0.22 & 0.12 & 0.35 & 0.0642 & 0.0156 & 28.59 \\
\hline ASL_H & 17 & 0.20 & 0.10 & 0.25 & 0.0534 & 0.0129 & 26.49 \\
\hline PA_INDEX & 17 & 0.31 & 0.19 & 0.39 & 0.0610 & 0.0148 & 19.88 \\
\hline LP/L & 15 & 42.16 & 31.25 & 51.61 & 5.7621 & 1.4878 & 13.67 \\
\hline ¿_tract & 15 & 0.69 & 0.50 & 0.83 & 0.1127 & 0.0291 & 16.42 \\
\hline
\end{tabular}

GIN EMM-20/69 (Fig. 11). The projective distance between posterior edge of incisor foramens and anterior edge of M1 is more than $0.2 \mathrm{~mm}$. The anterior edge of maxillo-palatine suture bears two indentations and projects as far as to the anterior part of hypocone and the posterior root of M1. The distance between alveoli of protocone roots of M1 is $2.8 \mathrm{~mm}$. The posteropalatine region is not preserved. In anterior view this specimen shows distal walls of incisor alveoli tightly contacting anterior roots of M1.

M1 (Tab. 4, Fig. 5). All studied molars have three roots. LRA1 is typically non-vergent so that the anterior wall of T1 (protocone) often runs parallel to the opposing anterior wall of BRA1. LRA3 approaching the right angle in younger individuals.
M2 (Tab. 5, Fig. 6). All molars in the collection have three roots. The anterior prism has distinctly triangular form. The sallow additional reentrant at the anterior face of the prism tend to excavate with wear.

M3 (Tab. 6, Fig. 7). Two-rooted specimens ( $n=13$, $81 \%$ ), though sometimes with flattened transversely ovoid anterior root, are predominant over rare treerooted teeth $(n=3,19 \%)$ with the bipartite anterior root. A strongly reduced lingual rootlet may occur $(n=2)$ below LRA2 (Fig. 7: 6). The anterior enamel islet is closed early in the ontogeny, it is shallow and shortlived in most specimens and its obliteration leads to the broad confluence of anterior cap and T2. The posterior enamel islet is irregularly present (Fig. 7: 3) and may be closed in some molars during older wear stages. T2 and 

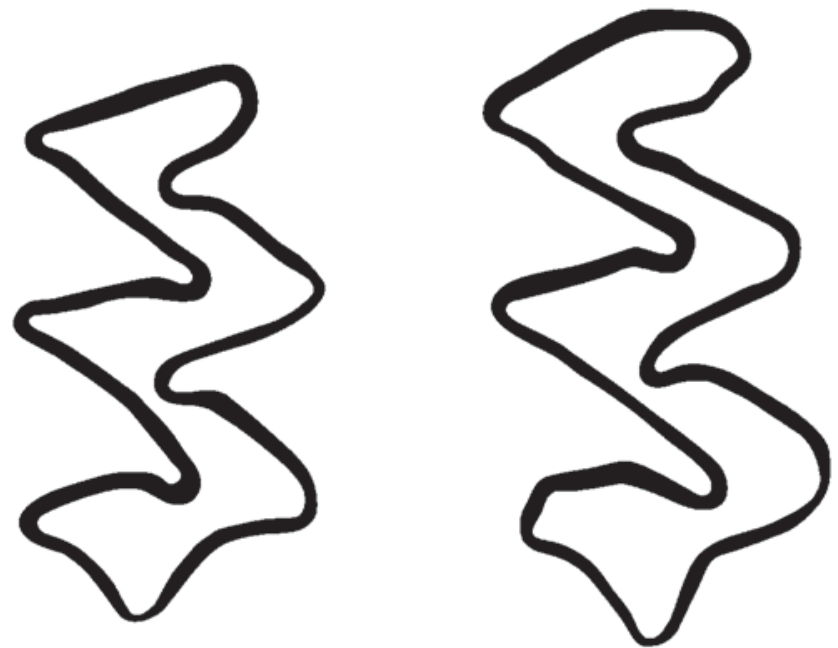

1

2

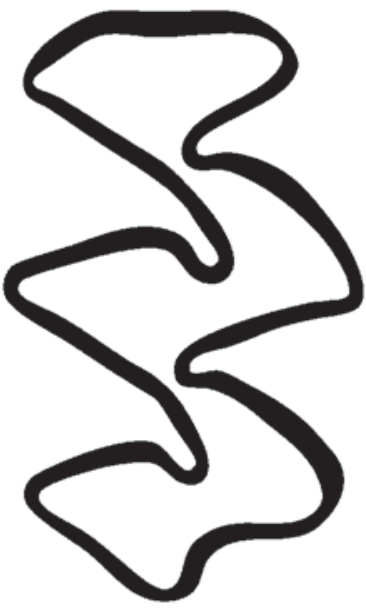

3
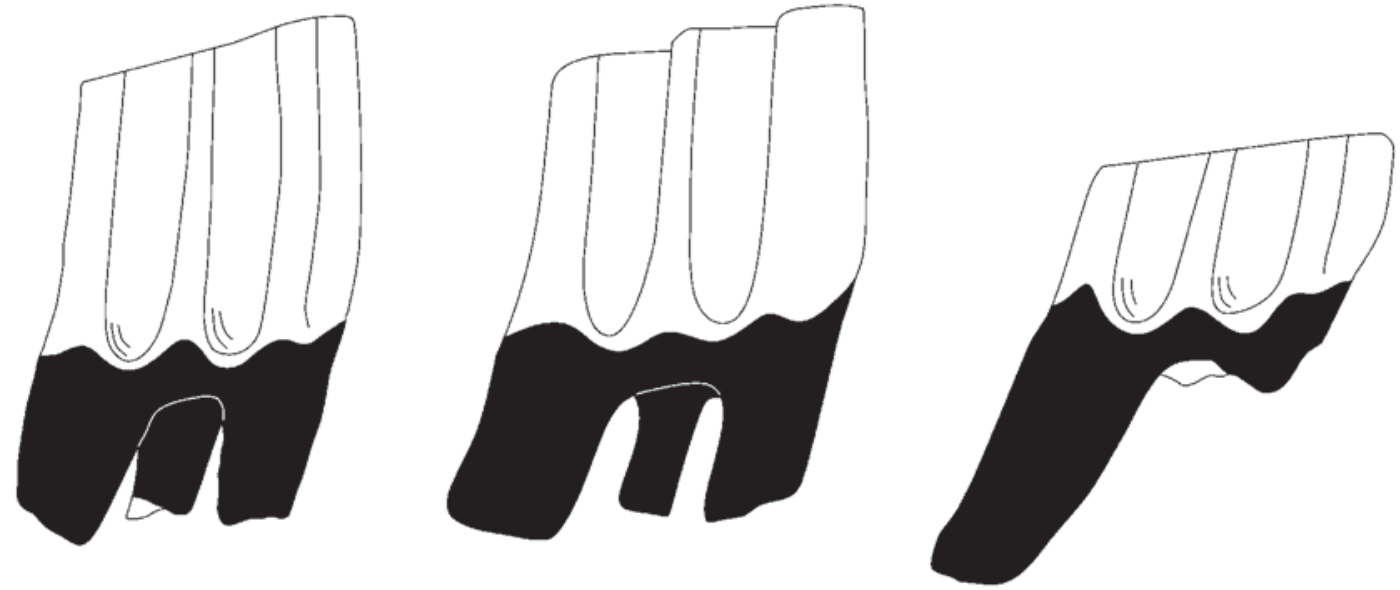

A
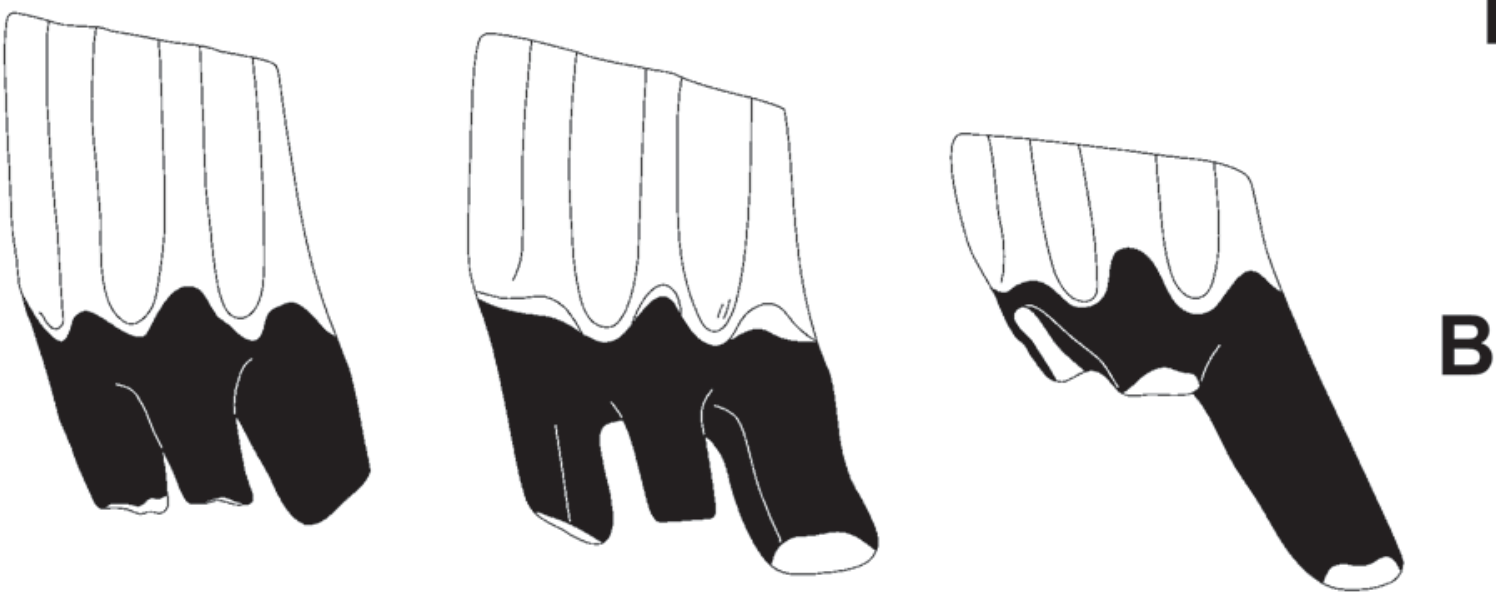

Figure 5. Pliomys destinatus sp. nov., M1, 1-3: occlusial surface, a: labial side, b: lingual side. 1. 20/73, 2. 20/72, 3. $20 / 81$. 2: reversed. Scale bar $1 \mathrm{~mm}$. 


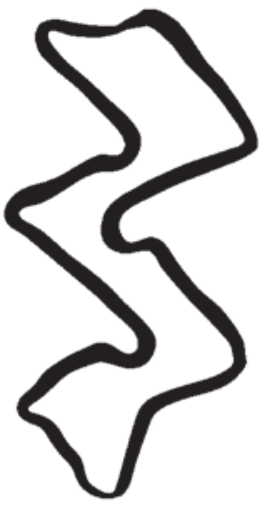

1
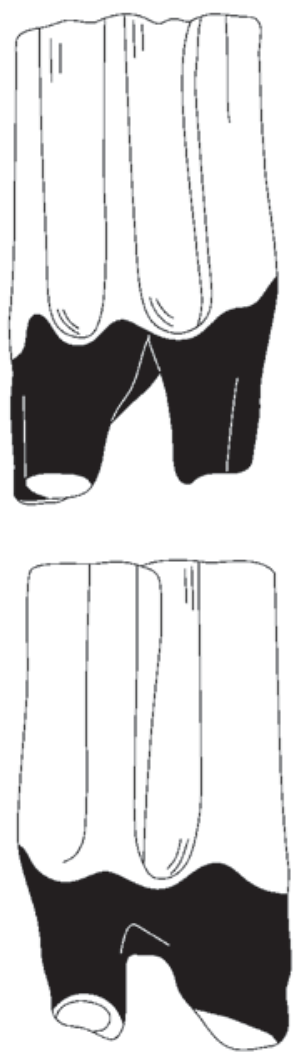

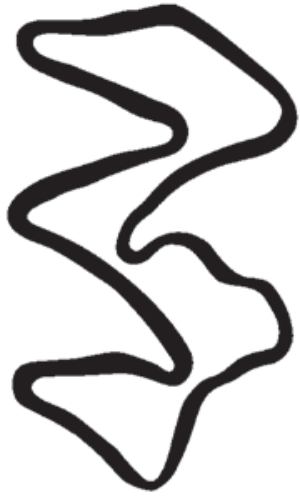

2
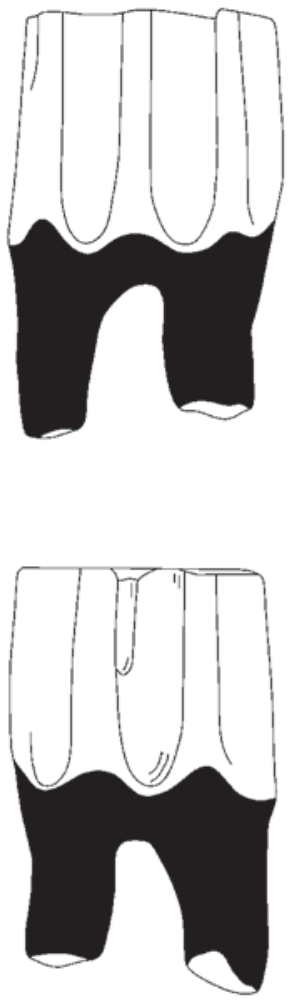

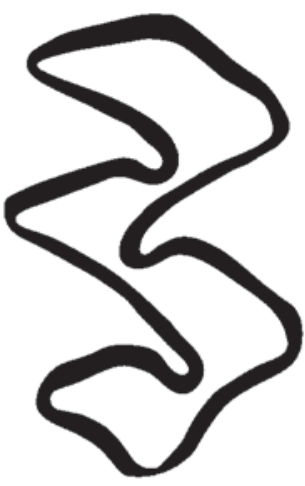

3
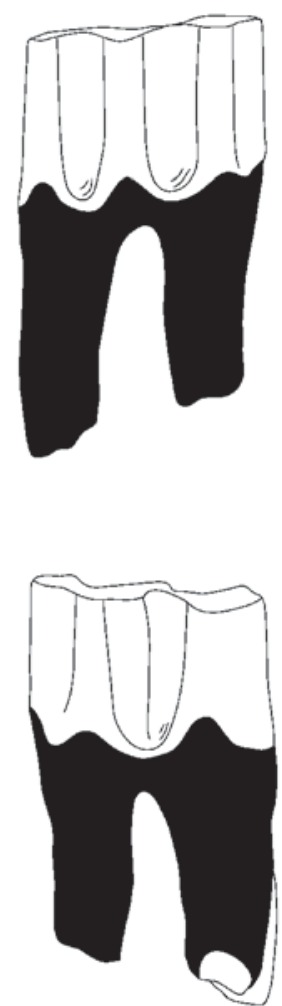
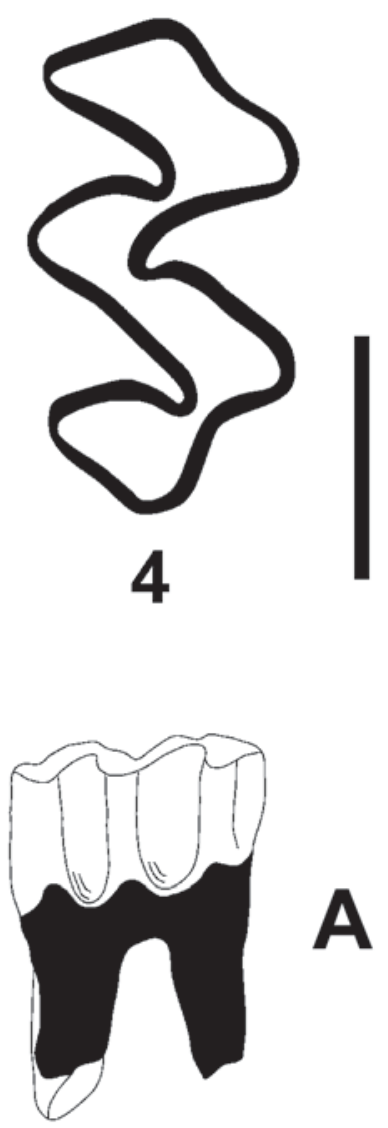

A

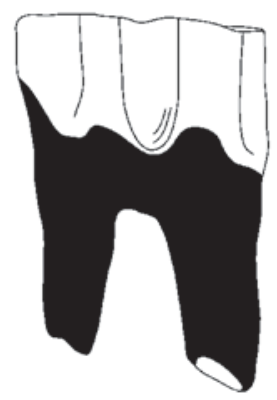

Figure 6. Pliomys destinatus sp. nov., M2, 1-4: occlusial surface, a: labial side, b: lingual side. 1. 20/113, 2. 20/96, 3. 20/97, 4. 20/109. Scale bar $1 \mathrm{~mm}$.

T3 are clearly separated by the tip (often curving) of LRA2. The posterior loop, with usually small T4, fuses with T3 at the labial side (Fig. 7: 2) or, much more typically, at the lingual side thus strongly reducing the communication with T3 (Fig. 7: 4).

Comparison. Pliomys kowalskii from Moskovei (Schevtschenko, 1965). The Odessa form differs from this late Ruscinian vole from Moldova in more reduced Mimomys-ridge, more advanced hypsodonty stage.
Pliomys moldavicus and Pliomys kowalskii from Etulia (Shushpanov, 1985) represent the single variable form of Pliomys close to the type P. kowalskii. This species shows strongly developed mimomyian ridge and BRA3 frequently insulated with wear. M3 show well developed posterior and anterior enamel islets. The Odessa Pliomys is clearly more advanced in higher hypsodonty, more reduced mimomyian features, including less frequent and more short-living enamel islets in $\mathrm{m} 1$ and $\mathrm{M} 3$. 


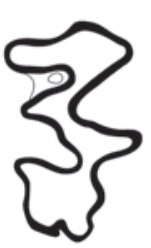

1

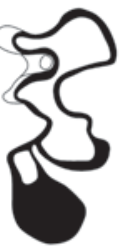

2

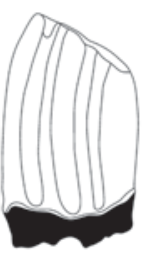

a
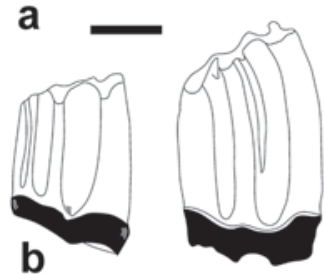

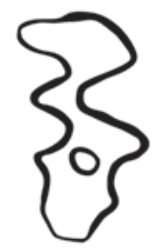

3
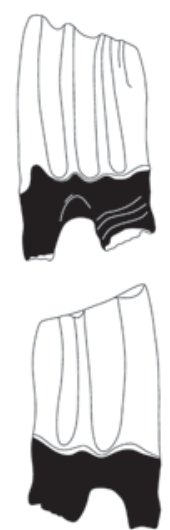

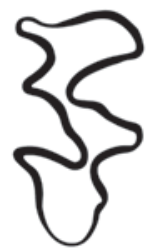

4
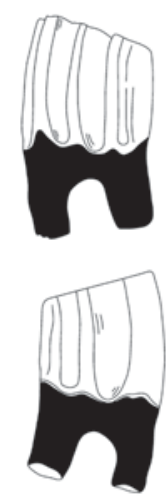

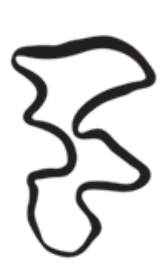

5
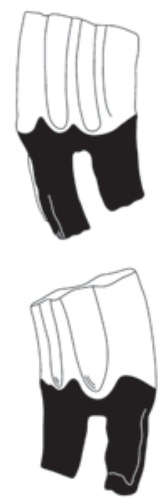

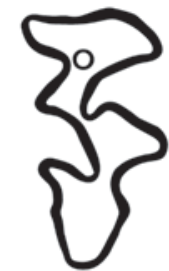

6
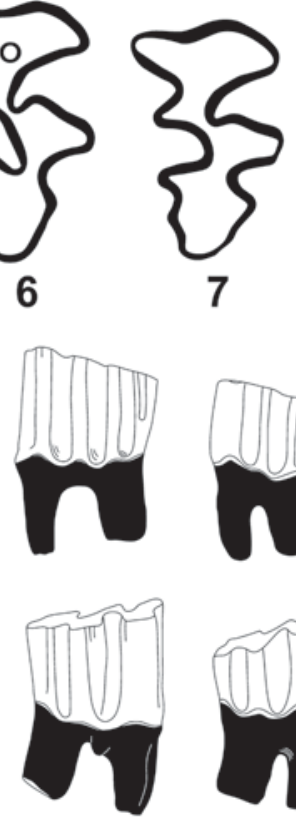

7

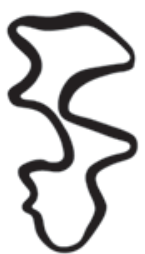

8
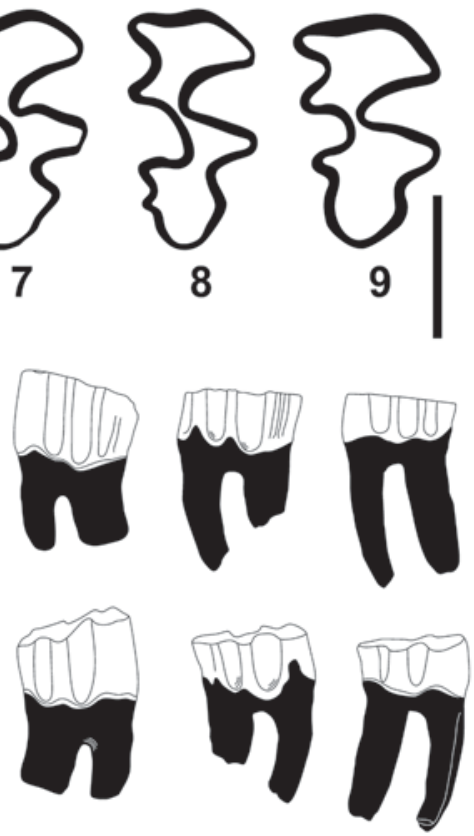

Figure 7. Pliomys destinatus sp. nov., M3, 1-9: occlusial surface, a: labial side, b: lingual side. 1. 20/65, 2. 20/68, 3. 20/64, 4. 20/51, 5. 20/59, 6. 20/52, 7. 20/66, 8. 20/53, 9. 20/67. 1, 6-9: reversed. Scale bar $1 \mathrm{~mm}$.
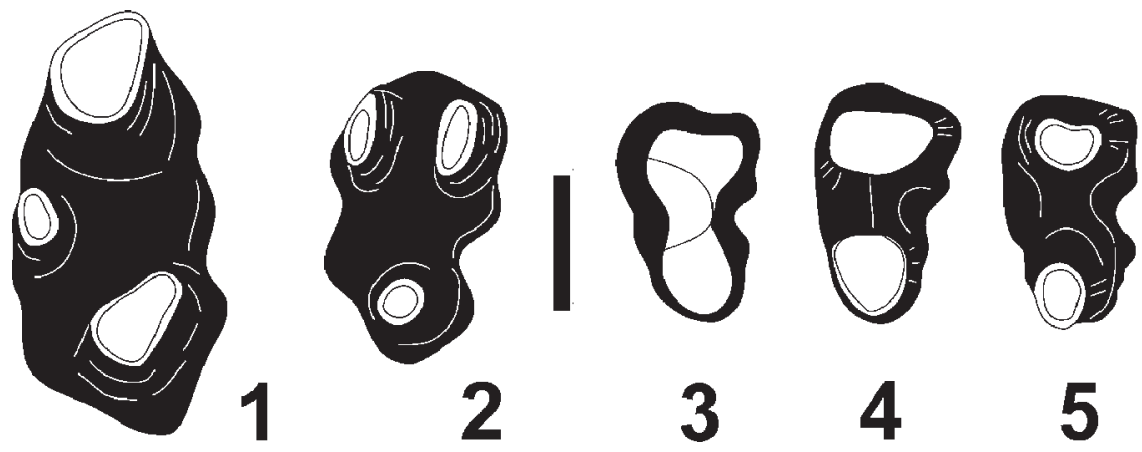

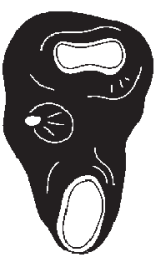

6

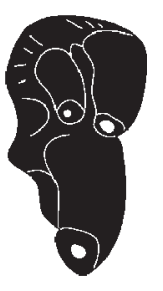

7

Figure 8. Pliomys destinatus sp. nov., upper molars, root view. 1. M1, 20/72, 2. M2, 20/109, 3-7: M3, 3. 20/65, 4. 20/68, 5. 20/51, 6. 20/52, 7. 20/67. 1, 6, 7: reversed. Scale bar $1 \mathrm{~mm}$.

Dolomys hungaricus from Csarnota 2 (Kormos, 1934; Kretzoi, 1959). The Hungarian vole is distinct from the Odessa Pliomys in larger size (on the average above $3.0 \mathrm{~mm}$ ), more complex structure of the anteroconid cap with distinct salient folds of the second complication in younger individuals, more vergent reentrants, more asymmetrical occlusial pattern of lower molars with enlarged lingual triangles, stronger reduction of mimomyan ridge and its morphological indicators, and in higher frequency of posterior enamel islets and three-rooted specimens of M3.

Dolomys ucrainicus Topachevsky \& Scorik, 1967. This advanced Pliomys species originates from the Cherevichnoe locality of late Early Villanyian age (MN16b). The Odessa Pliomys is smaller, much less hypsodont, has less complex $\mathrm{m} 1$, which preserve remnants of mi- momyiod morphology. However, Pliomys destinatus sp. nov. resembles $P$. ucrainicus in the overall dental morphology, especially conspicuous in juvenile and young specimens.

Pliomys graecus Bruijn \& Meulen, 1975 from Tourkobunia (MN16). This advanced Pliomys co-occurs with primitive cemented Mimomys. This species has $\mathrm{m} 1$ of arvaloid complexity stage, and it is indistinguishable from Pliomys ucrainicus. The new Odessa form is much less advanced both in hypsodonty and dental complexity than the Greek Pliomys.

Pliomys jalpugensis Nesin, 1983. This primitive species of Pliomys was analytically separated from the co-occurring Pliomys ucrainicus in the taphonomically mixed (see Tesakov, 2004) locality Kotlovina 2 in southern Ukraine (Nesin, 1983, Topachevsky \& Nesin, 

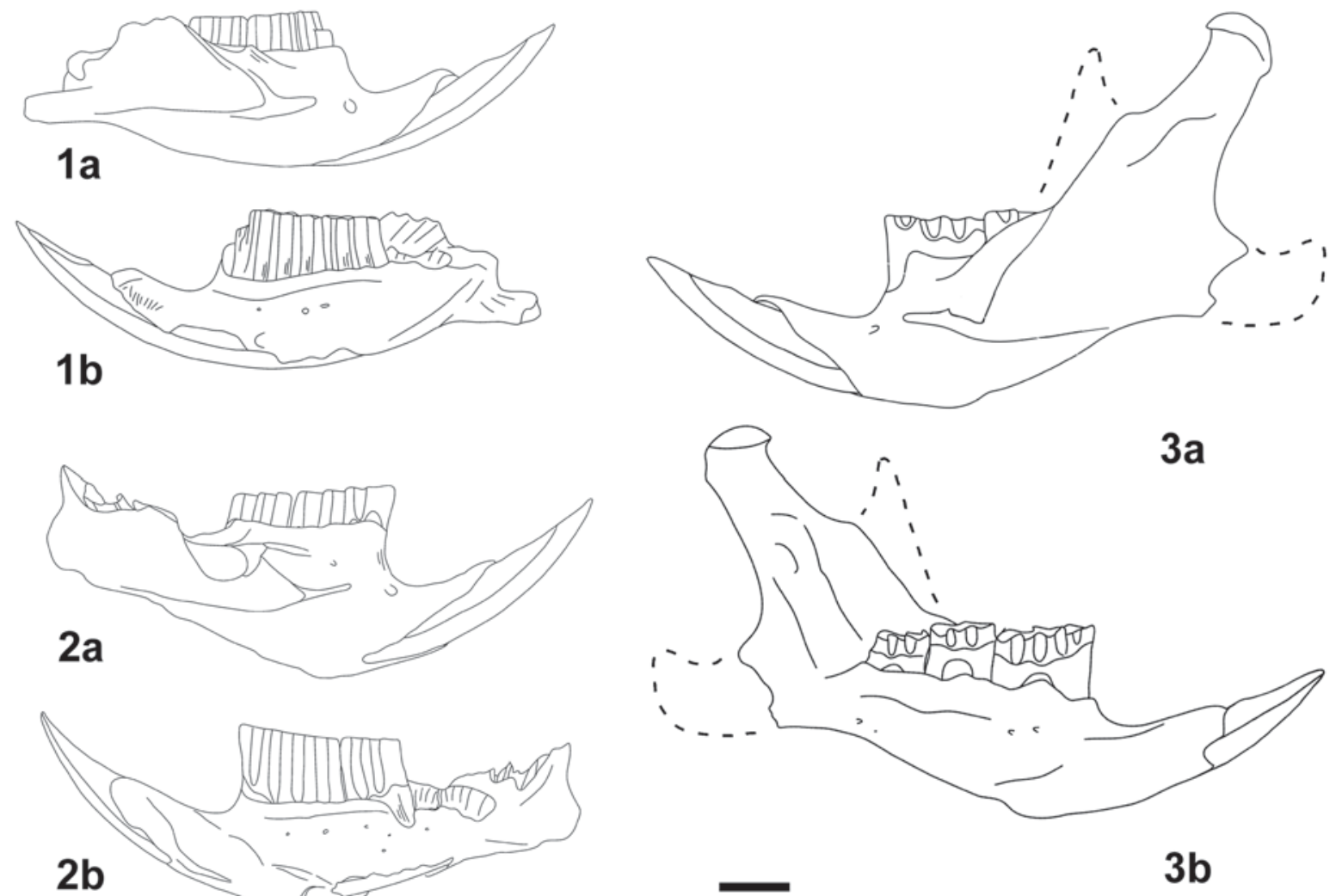

Figure 9. Pliomys destinatus sp. nov., fragments of mandibles, 1-3: lateral view, a: labial side, b: lingual side. 1. 3825-03, 2. 3825-01: holotype, 3. 20/14. Scale bar $0.5 \mathrm{~mm}$.
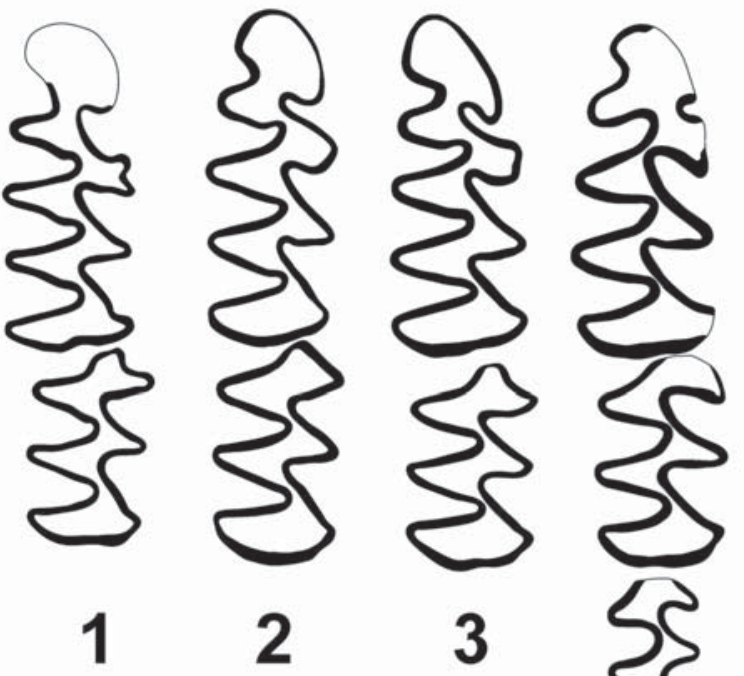

2

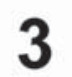

4

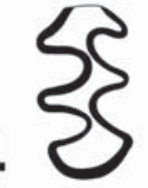

Figure 10. Pliomys destinatus sp. nov., mandibular tooth rows, 1-4: occlusial surface. $1 . \mathrm{m} 1-\mathrm{m} 2,3825-03,2$. $\mathrm{m} 1-\mathrm{m} 2$, 3825-01: holotype, 3. m1-m2, 3825-02, 4. m1-m3, 20/14. 4: inverted. Scale bar $1 \mathrm{~mm}$.
1989). It possibly represents an earliest Villanyian biochronologic level. The new species is distinct from $P$. jalpugensis in lower degree of hypsodonty, in less reduced Mimomys features in $\mathrm{m} 1$, in more curving BRA3, and in more rounded anterior cap of anteroconid. Most specimens (see Nesin, 1983, Fig.1: 1-4) in the described series of M3 of $P$. jalpugensis seem to represent a different, more brachiodont taxon, likely $P$. kowalskii, because the illustrated two-islet morphotypes are absent or extremely rare already at the stage of $P$. destinatus sp. nov. The two specimens of M3 that may actually belong to $P$. jalpugensis were illustrated by Nesin in his Fig. 1: 5 as P. jalpugensis, and in Fig. 2: 3 as $P$. ucrainicus.

Dolomys hungaricus from Węże 1 (Sulimski, 1964). This form is actually very similar to the species from Odessa Catacombs both in the stage of hypsodonty and the overall morphology. However, different pattern of dental variability possibly argues against the conspecifity of the two forms. Among distinctive features are notably less vergent reentrants, much simpler anteroconid caps in $\mathrm{m} 1$, more triangular anterior cap of M2, higher frequency of two-rooted M3, and generally deeper LRA3 of M3 in the Odessa form.

Promimomys moldavicus/Propliomys from Dranic (Radulescu et al., 1996). A sequence of small prom- 


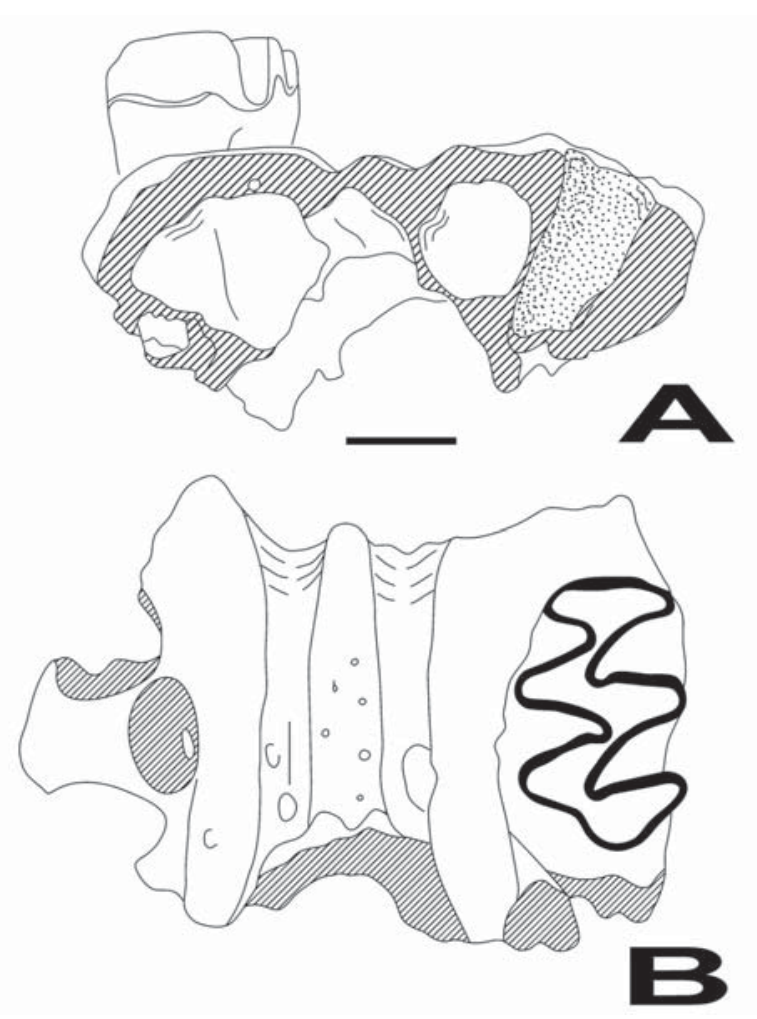

Figure 11. Pliomys destinatus sp. nov., fragment of maxillary bone, 20/69. a: anterior view, b: ventral view. Scale bar $1 \mathrm{~mm}$.

imyoid voles from several Late Ruscinian levels of this locality show the transitional morphology resembling $P$. kowalskii in a trend to reduction of enamel islet in $\mathrm{m} 1$ by its ontogenetically later insulation. The Odessa Pliomys differs from these forms in the same features as from $P$. kowalskii from Moldavian sites.

Propliomys hungaricus from Podari (Radulescu \& Samson, 1996). The form from this early Villanyian locality differs from the Odessa Pliomys in same features as the type $P$. hungaricus.

Remarks. I.M. Gromov (Gromov \& Polyakov, 1977) noted that the vole from Odessa Catacombs was preliminary studied by M. Kretzoi who had suggested the species name "odessanus" for it. Later, the species Dolomys odessanus Nesin, 1987 was described from the Late Ruscinian association of Kotlovina 1 (Nesin, 1987). Although, the Dolomys affinities of this poorly known form are quite possible, it cannot be excluded that it is congeneric with the vole from Odessa Catacombs. Therefore, I prefer to introduce a different name to avoid a possible homonymy.

Studies of Late Ruscinian vole associations are complicated by the insufficient degree of morphological divergence between numerous lineages of voles produced by the explosive radiation of mimomyoid voles. Many co-occurring forms of proto-Mimomys, Pliomys, and Dolomys evolutionary groups display a broad morphological overlap hampering isolation of pure dental

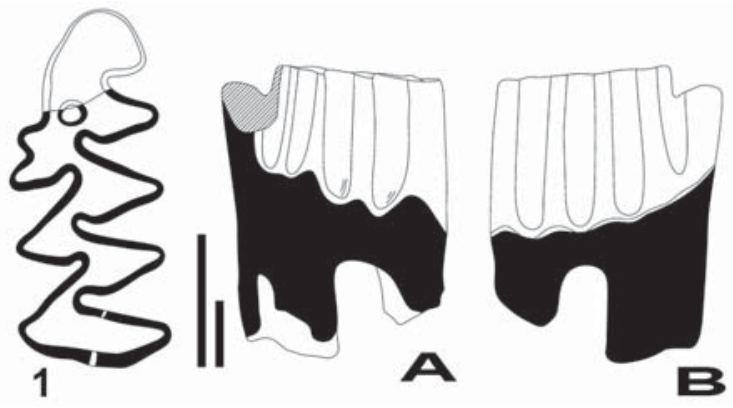

Figure 12. Promimomys sp., m1, 3825-05. 1: occlusial surface, a: labial side, b: lingual side. Scale bars $1 \mathrm{~mm}$.

series. The sample of Odessa Catacombs, possibly due to a certain environmental taphonomic filter, presents an exception with only one vole species strongly dominating in the association. Topachevsky \& Nesin (1989) noted the presence of Promimomys moldavicus along with Pliomys in the fauna of the Odessa Catacombs. In my mind, in most cases these authors took for Promimomys ontogenetically old specimens of Pliomys with enamel islets in $\mathrm{m} 1$. The studied materials show signs of a mixture in the sample of more than one species neither in sinumetry nor in occlusial morphology of molars. Noteworthy is the strong predominance of tworooted M3, another important indication of the Pliomys rather than Promimomys evolutionary level of the studied vole. However, a very rare presence of Promimomys admixture is probably indicated by the specimen OSM-3825/05 (Fig. 12).

Measurements. See Tables 1-6.

Occurrence. The type locality.

\section{Discussion}

The Pliomys species from Odessa Catacombs represents a very important transitional morphological stage between the Middle-Late Ruscinian array of small promimomyoid forms called Promimomys moldavicus and the Early Villanyian Pliomys lineage of the Black Sea Region. The main morphological trend within P. moldavicus towards Pliomys morphology was clearly shown by Radulescu \& Samson (1996). As to the particular descending group, I currently favour the phyletic linkage of $P$. destinatus $\mathbf{s p . ~ n o v . ~ w i t h ~ t h e ~ l i n e a g e ~ o f ~ P l i o m y s ~}$ jalpugensis - Pliomys ucrainicus (including Pliomys graecus). Pliomys hungaricus most probably represents a distinct, though related lineage. An array of nascent forms attributed to $P$. hungaricus, for example, from Węże (Kowalski, 1961, Sulimski, 1964) or Muselievo (Popov, 2004), actually represents more primitive stages, possibly ancestral to $P$. hungaricus or other later Pliomys lineages of Villanyian and Biharian age.

ACKNOWLEDGEMENTS. I thank K.K. Pronin (Odessa State University) for the great help during the sampling campaign, provision of additional material and encourage- 
ment of the work; M.A. Pevznert, E.A. Vangengeim, and M.V. Sotnikova for the help and collaboration in biostratigraphic and paleontological studies of fossil mammal in the southern Russia, Ukraine, and Moldova; late V.A. Topachevsky, Yu.A. Semenov, N.G. Podoplelova, N.A. Orlov, A.O. Averianov for the help with collections in their care. The work was supported by the Russian Foundation for Basic Research, project no. 02-05-64126.

\section{References}

Argyropulo A.I. \& Pidoplichko I.G. 1939a. [Recovery of a representative of Murinae (Glires, Mammalia) in Tertiary deposits of the USSR] // Doklady Akademii Nauk SSSR. T.23. No.2. P.209-212 [in Russian].

Argyropulo A.I. \& Pidoplichko I.G. 1939b. [Representatives of Ochotonidae (Duplicidentata, Mammalia) in Pliocene of Ukrainian SSR] // Doklady Akademii Nauk SSSR. T.24. No.7. P.723-724 [in Russian].

Bruijn H de. \& Meulen A. van der. 1975. The early Pleistocene rodents from Tourkobunia 1 (Athens, Greece) // Proceedings of the Koninklijke Nederlandse Akademie van Wetenschappen, Series B. Vol.8. No.4. P.314-338.

Gritzai T.G. 1938. [Paleontological excavations in karst caves of Odessa Catacombs] // Visti Akademii Nauk URSR. No.4. P.48-52 [in Ukrainian].

Gromov I.M. \& Polyakov I.Ya. 1977. [The Fauna of the USSR. Mammals. T.3. Vyp.8. Voles]. Leningrad: Nauka. 502 p. [in Russian].

Goretsky V.A. 1942. [Trogontherium and Castor from a cave of Pontian limestone of Odessa] // Priroda. No.3. P.71-72 [in Russian].

Gureev A.A. 1964. [The Fauna of the USSR. Mammals. T.3. Vyp.2. Lagomorpha]. Leningrad: Nauka. 276 p. [in Russian].

Havesson I.J. 1950. [Camels of the genus Paracamelus] // Doklady Akademii Nauk SSSR. T.52. No.5. P.917-920 [in Russian].

Kormos T. 1934. Neue Insektenfresser, Fledermäuse und Nager aus dem Oberpliozän der Villányer Gegend // Földtany Közlöny. Vol.64. S.296-321.

Kowalski K. 1960. Cricetidae and Microtidae (Rodentia) from the Pliocene of Węże (Poland) // Acta Zoologica Cracoviensia. Vol.5. No.11. P.447-506.

Kretzoi M. 1959. Insectivoren, Nagetiere und Lagomorphen der jüngpliozänen Fauna von Csarnóta im Villányer Gebirge (Südungarn) // Vertebrata Hungarica. Vol.1. No.2. P. 237-246.

Meulen A. van der. 1973. Middle Pleistocene smaller mammals from the Monte Peglia (Orivieto, Italy) with special reference to the phylogeny of Microtus (Arvicolidae, Rodentia) // Quaternaria. T.17. P.1-144.

Nesin V.A. 1983. [New finds of fossil voles of the genus Pliomys (Rodentia, Microtidae)] // Vestnik Zoologii. No.6. P.41-45 [in Russian].

Nesin V.A. 1987. [A new species of vole from the Middle Pliocene of the Ukraine] // Vestnik Zoologii. No.21.
P.77-78 [in Russian].

Nesin V.A. 1988. [Dental diagnostics of ancient Microtinae] // Vestnik Zoologii. No.2. P.84-87 [in Russian].

Nesin V.A. \& Nadachowski A. 2000. Late Miocene and Pliocene small mammal faunas (Insectivora, Lagomorpha, Rodentia) of Southeastern Europe // Acta Zoologica Cracoviensia. Vol.44. No.2. P.107-135.

Pevzner M.A., Vangengeim E.A., Vislobokova I.A., Sotnikova M.V. \& Tesakov A.S. 1996. Ruscinian of the territory of the former Soviet Union // Newsletters on Stratigraphy. Vol.33. No.2. P.77-97.

Popov V.V. 2004. Pliocene small mammals (Mammalia, Lipotyphla, Chiroptera, Lagomorpha, Rodentia) from Muselievo (North Bulgaria) // Geodiversitas. Vol.26. No.3. P.403-491.

Rabeder G. 1981. Die Arvicoliden (Rodentia, Mammalia) aus dem Pliozän und dem älterem Pleistozän von Niederösterreich // Beitragie zur Paläontologie von Österriech. No.8. 343 p.

Radulescu C. \& Samson P. 1996. Pliocene and Early Pleistocene arvicolids (Rodentia, Mammalia) of the Dacic Basin, Romania // Acta Zoologica Cracoviensia. Vol.39. No.1. P.401-406.

Schevtschenko A.I. 1965. [Key complexes of small mammals from Pliocene and lower Anthropogene in the south-western part of the Russian Plain] // Nikiforova K.V. (ed.). [Stratigraphic Significance of Anthropogene Fauna of Small Mammals]. Moskva: Nauka. P.7-57 [in Russian].

Shushpanov K.I. 1985. [Voles (Microtinae, Rodentia) from the Pliocene locality at Etulia village] // [Late Cenozoic Fauna and Flora of Moldavia]. Kishinev: Shtiintsa. P.2249 [in Russian].

Sotnikova M.V. 2004. [New data on the Pliocene carnivores of the fauna of Odessa Catacombs] // Gozhik P.F. (ed.). [Problems of Stratigraphy of the Phanerozoic of Ukraine]. Kiev: Institute of Geological Sciences, National Academy of Sciences of Ukraine. P.199-202 [in Russian].

Sulimski A. 1964. Pliocene Lagomorpha and Rodentia from Węże 1 (Poland) // Acta Paleontologica Polonica. Vol.9. No.2. P.149-244.

Topachevsky V.A. \& Nesin V.A. 1989. [Rodents of the Moldavian and the Khaprovian Faunistic Complexes of the Kotlovina Section]. Kiev: Naukova Dumka. 134 p. [in Russian].

Topachevsky V.A. 1969. [The Fauna of the USSR. Mammals. T.3. Vyp.3. Spalacids]. Leningrad: Nauka. 248 p. [in Russian].

Topachevsky V.A., Nesin, V.A. \& Topachevsky I.V. 1998. [Biozonal microtheriological scheme (stratigraphic distribution of small mammals, Insectivora, Lagomorpha, Rodentia) of the Neogene of the northern part of the Eastern Paratethys] // Vestnik Zoologii. Vol.32. No.1-2. P.76-87 [in Russian].

Topachevsky V.A. \& Scorik A.F. 1992. [Neogene and Pleistocene Lower Cricetids of the South East Europe]. Kiev: Naukova Dumka. 242 p. [in Russian]. 